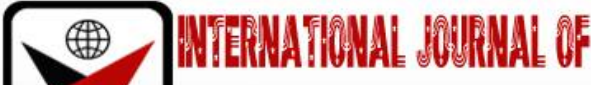

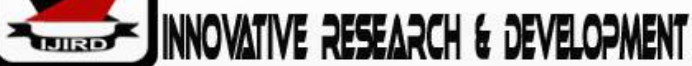

ISSN 2278 - 0211 (Online)

\section{Marketability of University Programs on the Employability of Graduates among Selected Corporate Institutions in Moshi Municipality, Tanzania}

Rachel C. Gatti
Student, Department of Marketing Management,
Mwenge Catholic University, Tanzania
Dr. Amembah A Lamu Amos
Lecturer, Department of Marketing Management,
Mwenge Catholic University, Tanzania
Dr. Hezron Onyancha
Lecturer, Department of Human Resource Management,
Mwenge Catholic University, Tanzania
Bernadette Temba
Assistant Lecturer, Department of Accounting,
Mwenge Catholic University, Tanzania
Innocent Bahati
Assistant Lecturer, Department of Project Planning and Management,
Mwenge Catholic University, Tanzania
Blandina Kori
Assistant Lecturer, Department of Strategic Management,
Mwenge Catholic University, Tanzania

\begin{abstract}
:
The study aimed at investigating the marketability of university programs on employability of graduates among selected corporate institutions in Moshi Municipality Tanzania. A mixed research approach was used. Under which explanatory sequential mixed research design was adopted. The researcher used simple random, snowball and purposive sampling techniques to select a sample size of seventy-five (75) participants. 30 students, 3 manufacturing industries, 3 educational institutions, 3 parastatals, and 3 service industries were selected using a simple random sampling technique while 20 alumni's students were selected using snowball sampling. The research also used structured questionnaires and interviews to collect data from the field. Instruments were validated through experts and reliability was calculated through the Cronbach's alpha coefficient for all the sections of the questionnaire from the results of the pilot study. Data was then coded and analysed through frequencies, percentages and means. The findings of the study showed that marketability and employability of university graduates is dependent on the skills that graduates acquire during their studies and the techniques used in delivering the programs. Universities should create better partnerships between various stakeholders in order to train marketable graduate who will meet and satisfy the market demands. In addition, graduates should be given opportunities to create positive relationships and develop better skills and experiences.
\end{abstract}

Keywords: University program, marketability, employability, university graduate

\section{Introduction}

The necessity to be better and competitive in the labour market has brought about a need for universities find strategies increasing their appeal to an ever-increasing and diverse student base. Successful branding and marketing have become increasingly important activities for institutions. Universities must now go to greater lengths to differentiate themselves from their competitors. Successful branding can help with increasing enrollment, expanding fundraising capabilities, and other outcomes (Hanover research, 2014).

An outstanding human capital assumption is that after completing higher education in the university, graduates should be able to make a successful transition from these institutions of higher to become productive employable, skillful workers, self-reliant entrepreneurs, responsible, good citizens, and selfless leaders. It is also presumed that after graduation, the graduates will develop additional skills through training and experience that further to boost their 
opportunities, capabilities and chances in life. Little \& Archer (2010), argue that the relative looseness in the relationship between higher education and the labor market has traditionally not presented problems for either graduates or employers, particularly in more flexible economies such as the United Kingdom. This may be largely due to the fact that employers have been reasonably responsive to generic academic profiles, providing that graduates fulfill various other technical and job-specific demands.

Furthermore, Mpanju (2012), found out that there is a mismatch between teaching in the institutions of learning and the needs of the labor market. Majority of students learn through lectures and academic textbooks and are academically sound but they have limited opportunities of acquiring practical experience by using machinery, equipment and practical techniques associated with their professions. There is also a lack of qualified teachers to: teach vocational, innovative, and entrepreneurial and job skills. Market statistics show that 33\% of the total population of the country is youth people, which also make $68 \%$ of the total active labor force (NBS-ILFS, 2010). The youth unemployment problem in the country is characterized by lack of employment opportunities in both urban and rural areas which results in underutilization of the majority of the labor force.

\section{Research Questions}

- What is the perception of the graduates towards the marketability of university programs and employability?

- To what extent do university programs create employment in the market among the university graduates?

\section{Conceptual Framework}

The conceptual framework is illustrated below:

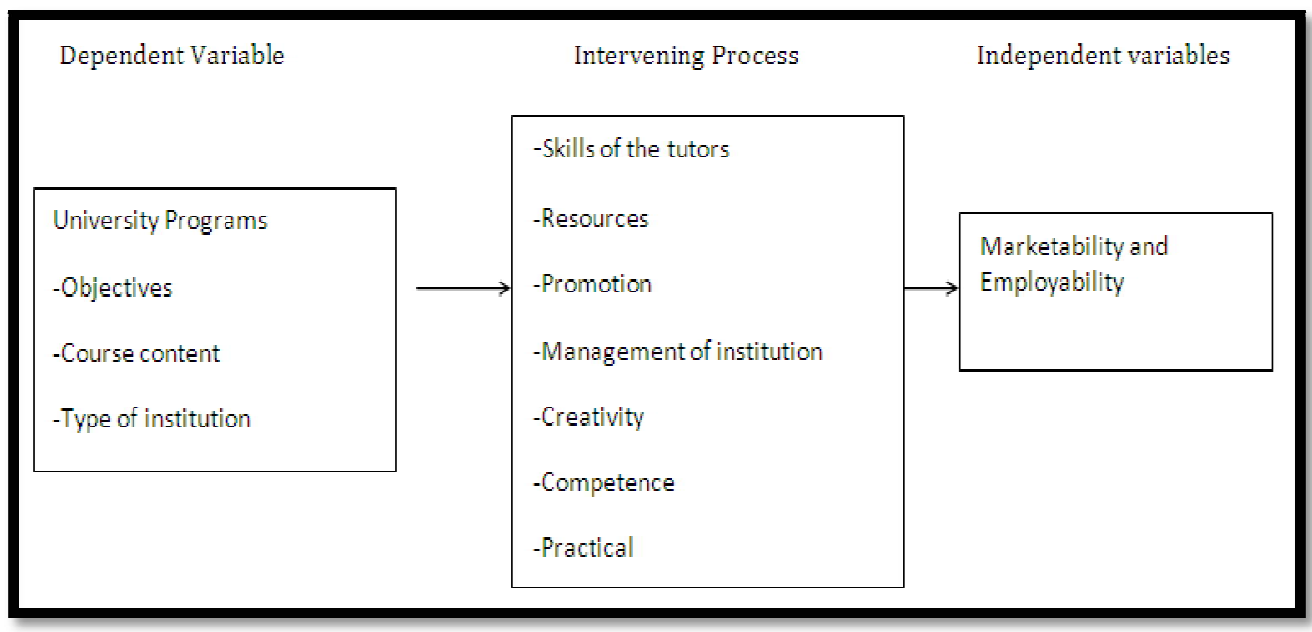

Figure 1

Source: Researcher's Own Construction, (2019)

\section{Literature Review}

The following literature review was undertaken to identify reliable findings. They are as follows:

\subsection{The Perceptions of the Graduates towards the Marketability of University Programs and Employability}

Research reveals a mixed picture about graduates and their position in the labor market (Brown and Hesketh, 2004; Elias and Purcell, 2004; Green and Zhu, 2010). More positive accounts of graduates' labor market outcomes tend to support the notion of Higher Education (HE) as a positive investment that leads to favorable returns. Elias and Purcell's (2004) research has reported positive overall labor market outcomes in graduates' early career trajectories 7 years on from graduation: in the main graduates manage to secure paid employment and enjoy comparatively higher earning than non-graduates.

They also reported high levels of satisfaction among graduates on their perceived utility of their formal and informal university experiences. Graduates in different occupations were shown to be drawing upon particular graduate skill-set (occupation-specific expertise, managerial decision-making skills, and interactive and communication-based competences). Less positively, their research exposed gender disparities gap in both pay and the types of occupations graduates work within. They found that a much higher proportion of female graduates work within public sector employment compared with males who attained more private sector and IT-based employment. This is further reflected in pay difference and breadth of career opportunities open to different genders.

Perhaps significantly, their research shows that graduates occupy a broad range of jobs and occupations, some of which are more closely matched to the archetype of the traditional graduate profession. Graduates clearly follow different employment pathways and embark upon a multifarious range of career routes, all leading to different experiences and outcomes. This is perhaps reflected in the increasing amount of new, modern and niche forms of graduate employment, including graduate sales managers, marketing and PR officers, and IT executives Barbee, (2001).

However, other research on the graduate labor market points to a variable picture with significant variations between different types of graduates. Various analysis of graduate returns (Brown and Hesketh, 2004; Green and Zhu, 
2010) have highlighted the significant disparities that exist among graduates; in particular, some marked differences between the highest graduate earners and the rest. While investment in Higher Education (HE) may result in favorable outcomes for some graduates, this is clearly not the case across the board. This is particularly evident among the bottomearning graduates who, as Green and Zhu show, do not necessarily attain better longer-term earnings than non-graduates do. Thus, graduates who are confined to non-graduate occupations, or even new forms of employment that do not necessitate degree-level study, may find themselves struggling to achieve equitable returns.

Research by Furlong and Cartmel (2005), Power, and Whitty (2006) shows strong evidence of socio-economic influences on graduate returns, Power and Whitty's research shows that graduates who experienced more elite earlier forms of education, and then attendance at prestigious universities, tend to occupy high-earning and high reward occupations. There are two key factors here. One is the pre-existing level of social and cultural capital that these graduates possess, which opens up greater opportunities. The second relates to the biases, employers harbor around different graduates from different universities in terms of these universities' relative so-called reputational capital (Brown and Hesketh, 2004). It appears that the wider educational profile of the graduate is likely to have a significant bearing on their future labor market outcomes.

The employability and labor market returns of graduates also appears to have a strong international dimension to it, given that different national economies regulate the relationship between Higher Education HE and labor market entry differently (Teichler, 2007). The Varieties of Capitalism approach developed by Hall and Soskice (2001) may be useful here in explaining the different ways in which different national economies coordinate the relationship between their education systems and human resource strategies. It is clear that more coordinated occupational labor markets such as those found in continental Europe (e.g., Germany, Holland and France) tend to have a stronger level of coupling between individuals' level of education and their allocation to specific types of jobs (Sorge, 2004).). In such labor market contexts, HE regulates more clearly graduates' access to particular occupations. This contrasts with more flexible liberal economies such as the United Kingdom, United States and Australia, characterized by more intensive competition, deregulation and lower employment tenure. In effect, market rules dominate. Moreover, in such contexts, there is greater potential for displacement between levels of education and occupational position; in turn, graduates may also perceive a potential mismatch between their qualifications and their returns in the job market

\subsection{University Programs and Employment in the Market among the University Graduates}

Loza (2004) identifies levels or processes for capacity building. These include the enabling environment in which people are facilitated to develop their knowledge, skills and attitudes. These environments determine the 'rules of the game' for interaction between and among organizations. In the process of developing knowledge, skills and attitude to enhance individual capacity the enabling environment include policies, legislation, power relations and social norms, all of which govern the mandates, priorities, modes of operation and civic engagement across different parts of society.

At the school level, the development of capacity comprises the internal policies, arrangements, procedures and frameworks that allow a school to operate and deliver on its mandate, and that enable teachers and students to work together to develop the envisaged capacities. This requires that schools are well-resourced with quality teachers, teaching materials, using quality teaching methodologies and appropriately assess the required capacities (Mbalamwezi, 2015). The UNDP reports did not stipulates if there is a relationship between the program from the school and the needs of the society thus is to say the program offered to the schools meets the students requirements solve the society needs therefore the research aims at finding the marketability and employability of the program offered at the university and higher learning institutions.

If all the environments, enabling environment and schools are well aligned to develop the capacities of the students, the students will gain necessary knowledge, skills, and experiences required to solve the perceived problems including access to employment. In the field of education, the development of human capacity is understood from different perspective, including humanistic, cognitive, as cognitive development where one is able to know and solve a problem. In terms of the work of schools, we typically think of cognitive development, as the knowledge required solving problems in the academic disciplines. Cognitive development includes not only knowledge of tasks in this case academic tasks but also knowledge of self, settings, and others (Mbalamwezi, 2015).

An understanding of one's identity is an important guidepost because it makes one realize his or her capacity, the likes and dislikes and build a range of networking and affiliations within and outside the school including in a workplace. This self-reflection lead into a conception of the job as interesting, doable, relevant, and whether it fits to individual competing goals (Spencer et al., 2003).The study did not focus on the marketability of the and employability of the programs offered to the university and higher learning institutions therefore the this study aimed at finding the employability and marketability graduates.

According to Lee (2008) knowledge of self involves one's identity as a member of a family, of peer social networks, and of larger communities, including those defined by ethnicity, race, and nationality (Lee, 2008; Rowley, Sellers, Chavous \& Smith, 1998). Knowledge of self also involves one's identity as a learner of particular field, subjects and in a school/ college in general (Briggs, A. R., Clark, J., \& Hall, I. (2012). As a participant who identifies to a greater or lesser extent with the culture of a classroom and a school (Wigfield, Eccles, \& Rodriguez, 1998). This study identified that an individual identify through family, social network but did not speculates if the university as the social phenomenon adds to the person self-knowledge therefore these study aims at finding if the program provided to the university offer someone self-knowledge that allow personal employments also the study did not speak about the how does knowledge of the self-come into someone mind of the person therefore the study aims a finding the contribution of university program toward the knowledge of the self that allows self-creation and applicability of the knowledge to the social factor 


\section{Research Design and Methodologies}

A mixed research approach was used whereby an explanatory sequential mixed design used according to a research approach used. Target Population was university graduates, secondary head teachers, and university students, managers from the industries, parastatal organizations and service centers. Description of Sample and Sampling Procedures: The researcher used simple random, snowball and purposive sampling techniques to select a sample size of seventy-five (75) participants. 30 students, 3 manufacturing industries, 3 educational institutions, 3 parastatals, and 3 service industries were selected using a simple random sampling technique while 20 alumni's students were selected using snowball sampling. The research also used structured questionnaires and interviews to collect data from the field. Instruments were validated through experts and reliability was calculated through the Cronbach's alpha coefficient for all the sections of the questionnaire from the results of the pilot study. Data was then coded and analysed through frequencies, percentages and means.

\subsection{Results and Discussions}

\subsubsection{Demographic Information of the Respondents}

This section represents the demographic information of the respondents which are graduates, cooperate institution university students and head Teachers corresponding to their age group. The table of information is summarized in table 4.2 .

\begin{tabular}{|c|c|c|c|c|c|c|c|c|c|c|c|}
\hline & \multicolumn{8}{|c|}{ Age group } & \multirow{2}{*}{\multicolumn{2}{|c|}{ Total }} \\
\hline & & \multicolumn{2}{|c|}{ 21-30 } & \multicolumn{2}{|c|}{$31-40$} & \multicolumn{2}{|c|}{ 41-50 } & \multicolumn{2}{|c|}{ above 50} & & \\
\hline & & $\mathrm{f}$ & $\%$ & $f$ & $\%$ & $\mathrm{~F}$ & $\%$ & $\mathrm{~F}$ & $\%$ & $\mathrm{f}$ & $\%$ \\
\hline \multirow{3}{*}{$\begin{array}{c}\text { Gend } \\
\text { er }\end{array}$} & Male & 37 & 49.3 & 9 & 12 & 5 & 6.7 & 2 & 2.7 & 53 & 70.7 \\
\hline & Female & 12 & 16 & 9 & 12 & - & - & 1 & 1.3 & 22 & 29.3 \\
\hline & otal & 49 & 65.3 & 18 & 24 & 5 & 6.7 & 3 & 4 & 75 & 100 \\
\hline
\end{tabular}

Table 1: Distribution of Respondent Demographic Information Based on Their Gender, and Age Group

Source: Field data, (2019)

\subsubsection{Gender}

Findings from the Table 4.1.1 indicate that, $49.3 \%$ of the respondents who participated in the study were male with age group 21-30, while $12 \%$ were male with age group 31-40, also $6.7 \%$ were male aged $41-50$ whereas only $2.7 \%$ were above 50 years of age and $16 \%$ of the total respondents who participated in the study were female with age group $21-30$, while $12 \%$ of them aged 31-40 while none of the female respondents with age group 22-26years respond to the questionnaire and only 1.3 of the respondents who respond to the field are aged above 50 years.

This indicates that the information required meets the needs of the finding this is due to the fact that the male and female are the one that study to the university at the age between twenty to thirty years, the finding revel that male are the one that were most participating in the finding that make to about forty nine percent of the total sample of the finding while only sixteen percent only are female that are at the age between twenty and thirty which are the school age with this finding male are the one making the majority of the students studying to the higher institution hence they are the one needed to the market.

\subsubsection{Age}

Table4.2 indicates that $65.3 \%$ of the respondents were aged between $21-30$ years while $24 \%$ had the age ranging between 31-40 years; whereas them was about $6.7 \%$ of age group $41-50$ years old and only $4 \%$ were age between $40-49$ years respond the questionnaire asked. Due to the result show most of the respondents responded to the questionnaire asked were aged between 21-30years.

This percent's indicates that most of the age group indicates that they are between the working age that's makes the a total of sixty fives percent's of the age group between twenty one and thirty percent according to this findings, with this results it indicates that the marketability of the of the university programs on employability among selected institutions toward university graduates are facing from the various university institution hence the students are those facing challenges on the selection courses that are marketable to the surrounding society. 


\begin{tabular}{|c|c|c|c|c|c|c|c|}
\hline & \multicolumn{5}{|c|}{ My Degree Offers Me Opportunity to Employment } & \multirow[t]{2}{*}{ Total } \\
\hline & & $\begin{array}{l}\text { Strongly } \\
\text { Agree }\end{array}$ & Agree & Undecided & Disagree & $\begin{array}{l}\text { Strongly } \\
\text { Disagree }\end{array}$ & \\
\hline \multirow[t]{2}{*}{ Gender } & male & $4.8 \%$ & $61.9 \%$ & $4.8 \%$ & $14.3 \%$ & $14.3 \%$ & $100.0 \%$ \\
\hline & female & & $83.3 \%$ & $12.5 \%$ & $4.2 \%$ & & $100.0 \%$ \\
\hline \multicolumn{2}{|c|}{ Total } & $2.2 \%$ & $73.3 \%$ & $2.2 \%$ & 13.3 & $2.2 \%$ & $100.0 \%$ \\
\hline & & \multicolumn{5}{|c|}{ My university degree is marketable } & \multirow[t]{3}{*}{ Total } \\
\hline & & strong agree & agree & disagree & strong & undecided & \\
\hline & & & & & disagree & & \\
\hline \multirow[t]{2}{*}{ Gender } & Male & $23.8 \%$ & $61.9 \%$ & $4.8 \%$ & $9.5 \%$ & & $100.0 \%$ \\
\hline & female & $25.0 \%$ & $54.2 \%$ & $16.7 \%$ & & $4.2 \%$ & $100.0 \%$ \\
\hline \multicolumn{2}{|c|}{ Tota } & $24.4 \%$ & $57.8 \%$ & $11.1 \%$ & $4.4 \%$ & $2.2 \%$ & $100.0 \%$ \\
\hline
\end{tabular}

Table 2: Showing the Relationship between Gender with Marketability and Employability of University Graduates

Source: Field Data (2019)

From the findings it shows that the majority of the females were respond that their degrees acquired offered to them employment as they are equipped with well skills and techniques relates to their programs offered rather than males whose the majority of them responded strong agree that their degrees acquired do not offered them employment opportunity in the market. Also, the findings indicates that majority of the males graduates responded by agree that their degrees are more marketable as their courses selected are demand of the market needs while the majority of the females responded that their degrees are not marketable because of the courses they select are not marketable and are at higher output.

\begin{tabular}{|c|c|c|c|c|c|c|c|}
\hline & \multicolumn{5}{|c|}{ The Program Provided by the University Are Marketable } & \multirow[t]{2}{*}{ Total } \\
\hline & & $\begin{array}{l}\text { Strongly } \\
\text { agree }\end{array}$ & Agree & Undecided & Disagree & $\begin{array}{l}\text { Strongly } \\
\text { Disagree }\end{array}$ & \\
\hline \multirow[t]{2}{*}{ Gender } & male & $19.0 \%$ & $71.4 \%$ & & $9.5 \%$ & & $100.0 \%$ \\
\hline & female & $12.5 \%$ & $58.3 \%$ & $8.3 \%$ & $8.3 \%$ & $12.5 \%$ & $100.0 \%$ \\
\hline \multicolumn{2}{|c|}{ Total } & $15.6 \%$ & $64.4 \%$ & $4.4 \%$ & $8.9 \%$ & $6.7 \%$ & $100.0 \%$ \\
\hline & & & \multicolumn{4}{|c|}{$\begin{array}{c}\text { Type of university i.e. private or } \\
\text { government }\end{array}$} & \multirow[t]{2}{*}{ Total } \\
\hline & & & \multicolumn{2}{|c|}{ yes } & \multicolumn{2}{|l|}{ No } & \\
\hline \multirow{2}{*}{\multicolumn{2}{|c|}{ Gender }} & Male & \multicolumn{2}{|c|}{$85.7 \%$} & \multicolumn{2}{|c|}{$14.3 \%$} & $100.0 \%$ \\
\hline & & female & \multicolumn{2}{|c|}{$75.0 \%$} & \multicolumn{2}{|c|}{$25.0 \%$} & $100.0 \%$ \\
\hline \multicolumn{3}{|c|}{ Total } & \multicolumn{2}{|c|}{$80.0 \%$} & \multicolumn{2}{|c|}{$20.0 \%$} & $100.0 \%$ \\
\hline
\end{tabular}

Table 3: Showing the Relationship between Gender with Type of Institution and the

Graduate That They Employ and the Programs Offered by University

Source: Field Data (2019)

The findings indicate that the majority of males were responded that programs provided by the university are marketable as they are selected because of the higher demand of the market hence are marketable while females responded that the programs offered by the university are not marketable. Likewise, the findings reveal that private universities have evolved as high quality learning centres and take credit for providing relatively better facilities and offering market-driven courses compared to government universities as the majority of male's graduates agree that private universities provide courses which are highly marketable.

\subsection{The Perception of the Graduates towards the Marketability of the University Programs on Employability}

The study sought to explore the perception of the graduates towards the marketability of the university programs on employability. In order to explore the perception of the graduates towards the marketability of the university programs on employability the respondents were asked questions related to the research objectives and the information obtained was summarized a Table. 


\begin{tabular}{|c|c|c|c|c|c|c|c|c|c|c|c|c|}
\hline \multirow[t]{2}{*}{ No. } & \multirow[t]{2}{*}{ Statements } & \multicolumn{2}{|c|}{ S. A } & \multicolumn{2}{|c|}{ A } & \multicolumn{2}{|c|}{ D } & \multicolumn{2}{|c|}{ S.D } & \multicolumn{2}{|c|}{ U.D } & \multirow[t]{2}{*}{ Mean } \\
\hline & & f & $\%$ & f & $\%$ & f & $\%$ & $\mathbf{F}$ & $\%$ & f & $\%$ & \\
\hline 1. & $\begin{array}{l}\text { University graduates are skilled } \\
\text { enough to allow self-employments }\end{array}$ & 12 & 16 & 37 & 49.3 & 19 & 25.3 & 5 & 6.7 & 2 & 2.7 & 2.18 \\
\hline 2. & $\begin{array}{l}\text { University programs allow practical } \\
\text { ability to the students }\end{array}$ & 10 & 13.3 & 47 & 62.6 & 11 & 14.7 & 3 & 4 & 4 & 5.3 & 2.27 \\
\hline 3. & $\begin{array}{l}\text { University programs provides } \\
\text { markets competition demands }\end{array}$ & 15 & 20 & 42 & 56 & 5 & 6.6 & 9 & 12 & 4 & 5.3 & 2.20 \\
\hline 4. & $\begin{array}{l}\text { University program provides } \\
\text { competent graduates }\end{array}$ & 9 & 12 & 51 & 68 & 6 & 8 & 8 & 10.6 & 7 & 9.3 & 2.31 \\
\hline 5. & $\begin{array}{l}\text { Is the program provided by the } \\
\text { university are marketable }\end{array}$ & 11 & 14.7 & 47 & 62.6 & 23 & 30.6 & 2 & 2.7 & 2 & 2.7 & 2.20 \\
\hline 6. & $\begin{array}{c}\text { Universities programs allows self- } \\
\text { perpetuation }\end{array}$ & 14 & 18.6 & 30 & 40 & 9 & 12 & - & - & 5 & 8.6 & 2.20 \\
\hline 7. & $\begin{array}{c}\text { Students allowed to select their } \\
\text { course with regard to the markets } \\
\text { demands }\end{array}$ & 13 & 11.4 & 26 & 34.6 & 9 & 12 & 3 & 4 & 1 & 1.3 & 2.18 \\
\hline 8. & $\begin{array}{l}\text { University programs have enough } \\
\text { recourse required during learning }\end{array}$ & 4 & 5.3 & 26 & 34.6 & 5 & 6.6 & 0 & 0 & 1 & 1.3 & 2.04 \\
\hline 9. & $\begin{array}{l}\text { University have competent experts } \\
\text { according to the program that it } \\
\text { offered }\end{array}$ & 3 & 4 & 28 & 37.3 & - & - & 3 & 4 & 1 & 1.3 & 2.16 \\
\hline
\end{tabular}

Table 4: The Perception of the Graduates towards the Marketability of the University Programs on Employability ( $\mathrm{N}=75)$

Sources; Field Data (2019)

Findings in Table 4.5 revealed respondents from the sampled secondary schools in Moshi district agreed that personality traits normally influence career choice. According to the findings $49.3 \%$ of respondents respond agree that University graduates are skilled enough to allow self-employments while $16 \%$ they just respond to strongly agree which show that University graduates are skilled enough to allow self-employments. Also (62.6\%) respond to agree and $13.3 \%$ just select agree, and $56 \%$ were agree and 20 were strongly agree to University programs provides markets competition demands, $68 \%$ were agree and $12 \%$ were respond to University program provides competent graduates, $62.6 \%$ were agree and $14.7 \%$ were respond to strong agree that Is the program provided by the university are marketable, also $40 \%$ were respond to agree and $18.6 \%$ they just say strong agree to Universities programs allows self-perpetuation, 34.6\% were agree and $11.4 \%$ were strongly agree to Students allowed to select their course with regard to the markets demands, also $34.6 \%$ were agree and 5.3 were strongly agree that University programs have enough recourse required during learning, lastly are about $37 \%$ agree and $4 \%$ just strongly agree that University have competent experts according to the program that it offered.

The findings indicates that various university programs are marketable to the students as majority of the respondent tend to agree by their responses that' the courses that they undertake are marketable to the allows them to be either employed or to be self employed by themselves this has being indicated from the finding where by majority responded as the university allows practical ability that allows them to be employed or for to be self-employed and also as the large mean (2.31) shows university programs provide competent graduate, likewise the finding revels that the knowledge that they got from the university is not full to allow some the graduates to cope with the society and hence makes them either not being employed or for self-employment fail to be undertaken by their courses they studded, this has been shown since minority responded as the courses that provided from the university are not marketable and the lowest mean(2.04)which shows that university programs have not enough resources required during learning. Also, the findings indicate that university programs provide market competition demands as majority of the respondent tend agree by their responses that programs offered by the university

Provides enough market competition demand that as indicated by the respondent from the findings that the majority of them were responded as the university programs provides competent graduates which allow them to be employed or self employed by themselves due to university programs offered have enough resources required during learning and students are allowed to select their course with regard to the market demands, this is indicated by the majority of the respondent to agree this point from the findings. Also the findings indicates that university programs allows self-perpetuation as the majority of the tend to agree by their responses that the programs offered by the universities allow self-perpetuation to allow them to be either employed or self employed by themselves and this has being indicated from the findings where by the majority responded as the program that it offered.

To What extent do university programs create employment in the market among the university graduates. The study sought to explore the extent do university programs create employment in the market among the university graduates. The respondents were asked questions related to the research objectives and the information obtained was summarized in Table 4.6 


\begin{tabular}{|c|c|c|c|c|c|c|c|c|c|c|c|c|}
\hline & \multirow[t]{2}{*}{ Statements } & \multicolumn{2}{|c|}{ S.A } & \multicolumn{2}{|c|}{$\mathbf{A}$} & \multicolumn{2}{|c|}{ D. A } & \multicolumn{2}{|c|}{ S. D } & \multicolumn{2}{|c|}{ U.D } & \multirow[t]{2}{*}{ Mean } \\
\hline & & $\mathbf{F}$ & $\%$ & f & $\%$ & f & $\%$ & $\mathbf{f}$ & $\%$ & $\mathbf{F}$ & $\%$ & \\
\hline 1 & $\begin{array}{l}\text { Degree holders always get best } \\
\text { employment opportunity }\end{array}$ & 6 & 8 & 37 & 49.3 & 22 & 29.3 & 6 & 8 & 4 & 5.3 & 2.36 \\
\hline 2 & $\begin{array}{l}\text { Further university programs } \\
\text { training increases the skills and } \\
\text { knowledge of market fields }\end{array}$ & 6 & 8 & 64 & 85.3 & 2 & 2.7 & 2 & 2.7 & - & - & 2.20 \\
\hline 3 & $\begin{array}{c}\text { University programs offered are } \\
\text { marketable }\end{array}$ & 11 & 14.6 & 57 & 76 & 6 & 8 & 1 & 1.3 & 1 & 1.3 & 2.20 \\
\hline 4 & $\begin{array}{l}\text { Level of education has good } \\
\text { reputation in the work }\end{array}$ & 8 & 10.6 & 55 & 73.3 & 7 & 9.3 & - & - & - & & 2.13 \\
\hline 5 & $\begin{array}{l}\text { The skills I acquired offer me } \\
\text { opportunity to be self employed }\end{array}$ & 7 & 9.3 & 61 & 75 & 7 & 9.3 & - & - & - & - & 1.98 \\
\hline 6 & $\begin{array}{l}\text { Psychology of university students } \\
\text { help them to be prepared for self- } \\
\text { employment }\end{array}$ & 16 & 21.3 & 48 & 64 & 8 & 10.6 & 2 & 2.7 & 3 & 4 & 1.96 \\
\hline 7 & $\begin{array}{c}\text { My university has a good name in } \\
\text { the market }\end{array}$ & 10 & 1.3 & 46 & 61.3 & 10 & 13.3 & 3 & 4 & 6 & 8 & 2.09 \\
\hline 8 & My degree has market oriented & 7 & 9.3 & 52 & 69.3 & 14 & 18.6 & - & - & 1 & 1.3 & 1.96 \\
\hline 9 & My degree is value oriented & 12 & 16 & 58 & 77.3 & 2 & 2.7 & - & - & 1 & 1.3 & 1.93 \\
\hline 10 & $\begin{array}{l}\text { University students they learn } \\
\text { university programs offered to be } \\
\text { employed }\end{array}$ & 11 & 14.6 & 17 & 22.6 & 12 & 16 & 2 & 2.7 & 2 & 2.7 & 2.20 \\
\hline
\end{tabular}

Table 5: Distribution of the extent to which university programs creates

Employment in the market among university graduates. $(\mathrm{n}=75)$

Source: field data (2019)

Findings in Table 4.6 revealed the extent do university programs create employment in the market among the university graduates. According to the findings $49 \%$ of respondent agree to Degree holders always get best employment opportunity as well as $8 \%$ also respond to strong agree to the same statement, also $85.3 \%$ they just agree and 8 they strong agree that Further university programs training increases the skills and knowledge of market fields, also $76 \%$ they agree where as $14 \%$ were strong agree that University programs offered are marketable, also $73.3 \%$ were just agree where $10.3 \%$ they strong agree that Level of education has good reputation in the work, the result also shows that $75 \%$ were agreed and 9.3\% were strongly agree to The skills I acquired offer me opportunity to be self-employed, also $64 \%$ were agree where as $21.3 \%$ were strong agree to Psychology of university students help them to be prepared for selfemployment, $61.3 \%$ were just agree and 1.3 were strongly agreed that My university has a good name in the market, also 69.3\% were agree and $9.3 \%$ were strongly agree that My degree has market oriented , $77.3 \%$ were just agree and 16\% were strongly agree to My degree is value oriented lastly were $22.6 \%$ were agree while 14.6 were strong agree to University students they learn university programs offered to be employed.

The finding reveal that the university program provides little opportunity of being employed unless for further program to be undertaken by the graduates. This is shown where by respondents strongly agree by only eight percent's that undergraduates gets best opportunity to employments after their study with this result it means that program provided from the university provides little contribution to graduates among employments to the graduates thus the lowest mean(1.93) also indicates that the degrees of graduates are not value oriented, While the institutions provides program that meets the market with to the medium level of knowledge on the particular program this has being indicated with the respondents whereby they agree with the statements that the program provided allows the graduates for the best employments hence either being employed or self-employed at a rates that's is at medium level. Also, the university provides small amounts to the students toward self-employments, the finding revel that university itself they are not structured by the philosophy of self-employments.

Also, the findings indicates that various university programs offered to the students are marketable as the majority of the respondents tend to agree that courses they undertake are marketable to allow them to be employed or self-employed by themselves this has being shown on findings that the majority responded that their degree has market and value oriented. Likewise, the findings reveal that the university has a good name in the market hence makes easy of the employment opportunity to the graduates and also the large mean (2.36) which shows that degree holders always get best employment opportunity.

\section{Findings of the Study}

In research question one, the findings indicate that various university programs are marketable due to the responses done by respondents, likewise the finding revels that not all students have been equipped well with the skills as the results they failed to be employed or self-employed, this has been only supported by minority of respondents. In research question two, the finding reveal that university programs only equip the graduates with few skills and techniques 
towards markets, but some of them went for further skills development while those still being in university they are taught with courses which are less marketable unless there are other extra course that will enable them to be employed.

\section{Conclusions and Recommendations}

The research investigated the marketability and employability of University graduates and the findings showed that most University programs were marketable since many respondents had obtained jobs. In addition, the study concludes that employment opportunities are given to those with the required skills and experiences. The study also concludes that the accessibility of the markets for university graduates to be employed depended on the skills and techniques from their studied programs and their experiences that could make them employable in reference to the studied programs.

Therefore, the study recommends that the university management should establish good working relationship with the private sectors, and government in order to help the continuous students and graduates to be allowed to have part time jobs that relates to their studies and enough time for field practices. In addition, the government should create policies that could develop the graduate's skills and experiences towards the labour market and employment.

\section{References}

i. $\quad$ Aduda, D. (2016). High Quality Learning Centers.UK: Cambridge University Press

ii. Bangser, M. (2008). Preparing High School Students for Successful Transitions to Post-secondary Education and Employment. London: Rutledge Publishers

iii. Becker, G. S. (1964). Human Capital: A Theoretical and Empirical Analysis, With Special Reference to Education, National Bureau of Economic Research. London: The University of Chicago Press Ltd

iv. Gyimah-Brempong, K., \& Kimenyi, M. S. (2013). Youth Policy and the Future of African Development. Africa Growth Initiative at Brookings. Working Paper 9.

v. Briggs, A. R., Clark, J., \& Hall, I. (2012). Building bridges: understanding student transition to university. Quality in Higher Education, 18(1), 3-21.

vi. Barbee, N. R. (2001). Communication skills training and development: What is the state of the art? (Doctoral dissertation).

vii. Brown, P., Hesketh, A., \& Williams, S. (2004). The mismanagement of talent: Employability and jobs in the knowledge economy. Oxford University Press on Demand.

viii. Elias, P., \& Purcell, K. (2004). Is mass higher education working? Evidence from the labour market experiences of recent graduates. National Institute Economic Review, 190(1), 60-74.

ix. Festus et al., (2012). Economic Growth and Development Vision. London: Oxford University Press

x. Furlong, K. \& Cartmel, O. (2005). Socio-economic influences on graduates returns. German: Sage Publishers Limited

xi. Green, U. \&Zhu, Y. (2010). Higher Education Labor Markets. China: Ghuanzue Publishers limited

xii. Green, F., \& Zhu, Y. (2010). Over qualification, job dissatisfaction, and increasing dispersion in the returns to graduate education. Oxford economic papers, 62(4), 740-763.

xiii. Hall, P. A., \& Soskice, D. (2001). An introduction to varieties of capitalism. op. cit, 21-27.

xiv. Hanover, R. (2014). Successful Brands in Marketing. South Africa: Pretoria Press

xv. Kehm, B. M., \& Teichler, U. (2007). Research on internationalisation in higher education. Journal of studies in international education, 11(3-4), 260-273.

xvi. ILO (1982).Statistics of the economically active population and employment. Paris: International Labor Office

xvii. ILO (2012).Global Employment Trends for the Youths". Switzerland: International Labor Office

xviii. ILO (2013).Employment trends for youth: A generation at risk International labor office Geneva. New York: Basic Books Publishers.

xix. ILO (2013).Global Employment Trends for Youths 2013.Switzerland: International Labor Office

xx. Juma, A. (2007).Promoting Livelihood Opportunities for Rural Youth. Academic

xxi. Lee, C. D. (2008). The centrality of culture to the scientific study of learning and development: How an ecological framework in education research facilitates civic responsibility. Educational Researcher, 37(5), 267.

xxii. Loza, J. (2004). Business-community partnerships: The case for community organization capacity building. Journal of Business Ethics, 53(3), 297-311. Book Publisher

xxiii. Little \& Archer, M. (2010).Higher Education and Labor Market. Paris: Academia Publishing Limited

xxiv. Mc-GurK, S. (2014).Youth employment in Sub-Saharan Africa. Senegal: States

xxv. Mbalamwezi, J. (2015). The Perspectives of Youths on Unemployment in Tanzania:-voices from Dodoma Municipal (Doctoral dissertation, The Open University of Tanzania). Publishers Limited

xxvi. Mjema, G. D. \& Kondylis, F. (1999). Youth unemployment in Tanzania Nature, Magnitude and proposals for solution. Dar es Salaam: EAMAT Publishers

xxvii. Mpanju, A. (2012).Employment Impact of Foreign Direct Investment. Lambert: Academic Publishing Limited

xxviii. Msigwa, R., \& Kipesha, E. F. (2013). Determinants of youth unemployment in developing countries: Evidences from Tanzania.

xxix. Nangale, S. (2012).Tanzania Economically Active Population. Dar es Salaam: APE Book Publishers

xxx. Power, S., \& Whitty, G. (2006). Education and the middle class: A complex but crucial case for the sociology of education. Oxford University Press.

xxxi. Rowley, S. J., Sellers, R. M., Chavous, T. M., \& Smith, M. A. (1998). The relationship between racial identity and selfesteem in African American college and high school students. Journal of personality and social psychology, 74(3), 
715.

xxxii. Sorge, A. (2004). Cross-national differences in human resources and organization. International human resource management, 2, 117-140.

xxxiii. Spencer, J. W. (2003). Firms' knowledge-sharing strategies in the global innovation system: empirical evidence from the flat panel display industry. Strategic management journal, 24(3), 217-233.

xxxiv. Theodore, W. S. \&Gary, B. (1960).The Human Capital. London: Academic Books Publishers

xxxv. URT (1995).The National Education and Training Policy for Tanzania: United Republic of Tanzania. World Bank, (2014) youth unemployment rate, database. http:/ / www.go.worldbank.org/ OS6V7NIUD0

xxxvi. Wigfield, A., Eccles, J. S., \& Rodriguez, D. (1998). Chapter 3: The development of children's motivation in school contexts. Review of research in education, 23(1), 73-118.

xxxvii. Yeoden, A. (2010). University Graduates Skills. United States of America: Harvard University Press. 